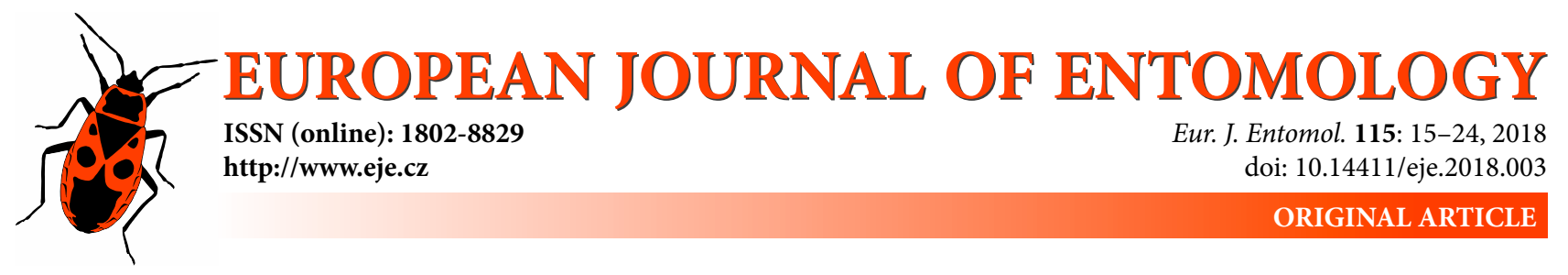

\title{
Efficiency of pitfall traps with funnels and/or roofs in capturing ground-dwelling arthropods
}

\author{
Péter CSÁszÁR, Attila torma, Nikolett GAlLÉ-SZPISJAK, Csaba tölgyesı and Róbert GALLÉ
}

Department of Ecology, University of Szeged, Közép fasor 52, Szeged H-6726, Hungary; e-mails: csaszar.peter7@gmail.com, torma_a@yahoo.com, szpisjak.n@gmail.com, festuca7@yahoo.com, galle.robert@gmail.com

Key words. Araneae, spiders, Carabidae, ground beetles, funnel pitfall trap, trap roof, ground-dwelling

\begin{abstract}
Pitfall traps are widely used for sampling ground-dwelling arthropods. Their sampling efficiency is affected by several factors, e.g. material, size and modification of parts of the trap and sampling design. Pitfall trap sampling is also affected by the accumulation of plant litter in the traps, rain fall and by-catches of small vertebrates, which may cause a bias in the catch by obstructing traps or attracting certain insects. A roof that prevents rain and plant litter entering a trap, prevents dilution of the preservative and escape of arthropods. The main goal of present study was to compare the effect of four types of differently combined funnel and roof pitfall traps on the capture efficiency of epigeal arthropods. We found that a funnel and/or a roof had no effect on spider catches. Total abundance of large carabids and thus the total abundance of ground beetles was lower in funnel pitfall traps without a roof than in other types of traps. However, funnel pitfall traps with roofs collected significantly more carabid beetles, especially individuals of those species that are large or good fliers. We conclude that funnel pitfall traps with roofs have no negative effects on capture efficiency of ground beetles and spiders, therefore application of this sampling technique is strongly recommended.
\end{abstract}

\section{INTRODUCTION}

Choosing the most efficient method of sampling is crucial in studies aiming to compare invertebrate assemblages (Ernst et al., 2015). Pitfall traps are the most widely used tools for sampling ground-dwelling arthropods in ecological studies and monitoring programs (Southwood \& Henderson, 2000; Babin-Fenske \& Anand, 2010; Da Silva et al., 2011; Isaia et al., 2015; Brown \& Matthews, 2016). Pitfall traps are easy to transport and install; they cost little, cause relatively low disturbance and can yield a large number of individual invertebrates and species (New, 1998; Woodcock, 2005; Santos et al., 2007). Usually, traps consist of plastic or glass containers that are dug into the ground with the top flush with ground level (Brown \& Matthews, 2016). In most studies, traps contain a preservative fluid to prevent arthropods from escaping and preserve the material collected (Jud \& Schmidt-Entling, 2008; Knapp \& Ruzicka, 2012). However, there are various types of pitfall traps, which also incorporate barriers, drift-fences, funnels, roofs or special components such as baits and time-sorters (Woodcock, 2005; Brown \& Matthews, 2016).

Many studies demonstrate that catches of pitfall traps are influenced by a number of factors; the technical parameters, such as the diameter of the cup (Baars, 1979; Santos et al., 2007), preservative fluid (Pekár, 2002; Schmidt et al., 2006), trap material (Luff, 1975; Koivula et al., 2003) and spacing (Baker \& Barmuta, 2006; Schirmel et al., 2010), which can be adjusted. Other factors are specific to the environment like habitat structure (Melbourne, 1999; Lang, 2000) or temperature (Saska et al., 2013 ) and the target group of invertebrates (like their typical abundance, activity and catchability) (Southwood \& Henderson, 2000) and cannot be changed by the investigator. The optimal trap efficiently collects invertebrates with minimal bias and reduce by-catches of non-target animals (New, 1999; Buchholz et al., 2011; Lange et al., 2011). The aim of the present study was to compare the sampling efficiency of different types of pitfall traps. We specifically tested how the addition of a funnel and/or a roof to the traps affects the catches of two invertebrate predator taxa, carabids and spiders. We hypothesized that the use of funnel pitfall trap with a roof does not have a negative effect on the efficiency with which it captures invertebrates.

\section{MATERIAL AND METHODS}

This study was conducted in 2014, from May to October in a forest-wet meadow complex at Turjánvidék, Central Hungary $\left(46^{\circ} 43^{\prime} \mathrm{N}, 19^{\circ} 20^{\prime} \mathrm{E}\right)$. The climate is continental; the annual precipitation is a $500-600 \mathrm{~mm}$ and the mean annual temperature is 10-1 $1{ }^{\circ} \mathrm{C}$ (Bíró et al., 2013; Tölgyesi et al., 2015). Grasslands were mowed once a year, at the beginning of July. The dominant species of trees in the forest patches include narrow-leafed ash (Fraxinus angustifolia) and English oak (Quercus robur).

We compared four types of pitfall traps: (1) conventional pitfall trap without a roof, (2) conventional pitfall trap with a roof, 


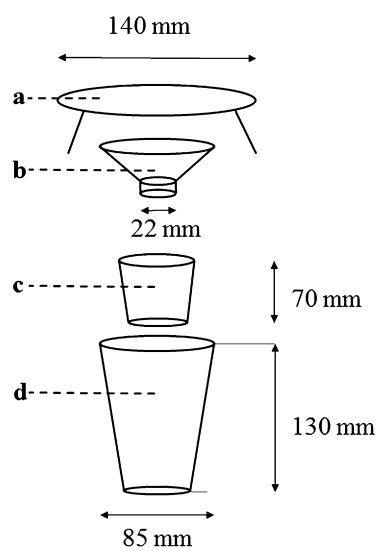

A

Fig. 1. Exploded view of a pitfall trap (a) and the layout of the sampling scheme (b). Conventional traps without a roof included only component $d$, conventional traps with a roof components $d+a$, funnel pitfall traps without a roof $d+c+b$, funnel pitfall traps with $a$ roof $d+c+b+a$. Abbreviations of components: $a-$ roof, $b-$ funnel, $c-$ small cup, $d-$ large cup.

(3) funnel pitfall trap without a roof and (4) funnel pitfall trap with a roof (Fig. 1). All traps were $500 \mathrm{ml}$ white plastic cups; the roofs were made of white plastic plates held in position, ca. $3-5 \mathrm{~cm}$ above the surface using $100 \mathrm{~mm}$ plastic sticks, and the funnels were cut out of $1500 \mathrm{ml}$ transparent plastic bottles (PET, polyethylene terephthalate). The funnel pitfall traps also had an additional small transparent plastic cup for easier handling of the collected material and to prevent the funnel collapsing into the larger plastic cup.

We used 50\% ethylene-glycol dissolved in water as a preservative and a few drops of odourless detergent to break the surface tension (Koivula et al., 2003; Schmidt et al., 2006). We established ten sampling sites in forest patches and ten in adjacent grassland. Four traps (one of each type) were placed at random in a quadrate at each site, with $8 \mathrm{~m}$ between the traps, this trap distance corresponds to the recommended minimum space between traps (Perner \& Shueler, 2004; Zhao et al., 2013). As our aim was to directly compare the capture efficiency of different types of traps we chose a relatively short distance in order to minimize the influence of differences in microhabitat conditions within sites (Lange et al., 2011). Although a small distance between traps may have decreased the numbers of invertebrates captured (e.g.Ward et al., 2001), it would, however, have had a similar effect on all the traps due to the random design. The closest sites were at least $50 \mathrm{~m}$ apart to reduce spatial autocorrelation between samples (Fig. 1). In total, we installed 80 traps, two habitats $\times$ ten sampling sites $\times$ four traps. Sampling was conducted in three periods in 2014, between May 5 and 12, July 24 and August 1, and October 9 and 20 (further information is given in Table S1).

Adult spiders and carabid beetles were identified to species level according to Nentwig et al. (2014) and Freude et al. (2004) and were sorted into size classes in order to test the sampling ef- ficiency for a bias according to size (large species $>10 \mathrm{~mm}$ and small species $<10 \mathrm{~mm}$ ). Furthermore, spiders were classified according to hunting strategy (web builders and hunters) and main stratum (ground and vegetation) following Buchar \& Ruzicka (2002) and Cardoso et al. (2011). It is generally accepted that flying ability decreases with increasing body size in carabid beetles (Blake et al., 1994; Ribera et al., 2001; Martinson \& Raupp, 2013). Therefore, size and flying ability were not used as separate traits in this study. Alternatively, two body size categories (small $(\mathrm{S})<10 \mathrm{~mm}$ and large $(\mathrm{L})>10 \mathrm{~mm}$ ) and three flight ability categories (brachypterous or dimorphic wings, no flight muscles (F1); polymorphic wings and polymorphic flight muscles (F2); macropterous species, functional flight muscles (F3)) were combined into six classes (S-F1, S-F2, S-F3, L-F1, L-F2, L-F3). The categories of flying ability were based on Hurka (1996), Freude et al. (2004) and the database carabids.org (Homburg et al., 2014). Designation of body length follows Brust (1990), Pihlaja et al. (2006) and Sint \& Traugott (2015). Voucher specimens were deposited in the invertebrate collection of the University of Szeged.

Data from the three sampling periods were pooled prior to analysis. The effect of funnel and roof on spider and carabid species richness and the abundances of functional groups were tested using mixed-effect general linear models (GLMM) with a poisson error term, typically used for count data and with a quasipoisson error term if we detected overdispersion in the data (Crawley, 2007). (R, lme4 package: version 1.1.12, glmer function; MASS package: version 7.3.23, glmmPQL function). The effect of roof (present versus absent), funnel (present versus absent) and their interaction (roof $\times$ funnel) were treated as the fixed effects. To incorporate possible effect of spatial autocorrelation and differences in the structure of vegetation among sites, sampling site within habitat type (forest versus grassland) was used as the random effect. Separate models were run for forests and grasslands if the variability within a trap type was largely explained by the variance of the random effect. In this case, sampling site was the random effect. For goodness of fit, marginal and conditional Rsquared values were estimated for the GLMM.

The statistical calculations were performed using the software R (version 3.3.2) (R Development Core Team, 2013).

\section{RESULTS}

In total, of 3279 spiders (2792 adults) and 2698 carabid beetles were collected, which belonged to 100 and 67 species, respectively (see Tables S2a-b and S3a-b). Distributions of the species and individuals caught by the different types of traps are given in Table 1. Furthermore, 45 vertebrates were caught, but pitfall traps with funnels caught fewer vertebrates: one amphibian and one mammal (see Table S4).

The species richness of spiders was not influenced by the type of trap (roof: $\mathrm{z}=0.09, \mathrm{P}=0.929$; funnel: $\mathrm{z}=-1.38, \mathrm{P}$ $=0.166$; funnel $\times$ roof: $\mathrm{z}=0.86, \mathrm{P}=0.387$, marginal $\mathrm{R}^{2}=$ 0.028 , conditional $\mathrm{R}^{2}=0.153$ ). Furthermore, there was no

Table 1. The means $(\mu)$ and standard errors $(S E)$ of the numbers of species and individuals caught by the different types traps. Abbreviations: conv - conventional, $\mathrm{S}$ - number of species, $\mathrm{N}$ - number of individuals, $\mathrm{a}-$ roof, $\mathrm{b}-$ funnel, $\mathrm{c}-$ small cup, $\mathrm{d}$ - large cup.

\begin{tabular}{|c|c|c|c|c|c|c|c|c|c|}
\hline \multirow{3}{*}{$\begin{array}{l}\text { Type } \\
\text { Element } \\
\end{array}$} & & \multicolumn{2}{|c|}{ conv. pitfall } & \multicolumn{2}{|c|}{ pitfall + roof } & \multicolumn{2}{|c|}{ funnel pitfall } & \multicolumn{2}{|c|}{ funnel pitfall + roof } \\
\hline & & \multicolumn{2}{|c|}{$\mathrm{d}$} & \multicolumn{2}{|c|}{$d+a$} & \multicolumn{2}{|c|}{$d+c+b$} & \multicolumn{2}{|c|}{$d+c+b+a$} \\
\hline & & $\mu$ & $S E$ & $\mu$ & $S E$ & $\mu$ & $S E$ & $\mu$ & $S E$ \\
\hline \multirow[t]{2}{*}{ Spiders } & $S$ & 12.50 & 0.87 & 12.40 & 0.77 & 11.00 & 0.83 & 12.20 & 0.80 \\
\hline & $\mathrm{N}$ & 32.35 & 3.40 & 38.80 & 3.00 & 30.85 & 4.01 & 37.6 & 3.47 \\
\hline \multirow[t]{2}{*}{ Carabids } & $\mathrm{S}$ & 7.45 & 0.83 & 6.60 & 0.82 & 6.90 & 0.92 & 7.40 & 0.92 \\
\hline & $\mathrm{N}$ & 40.75 & 9.61 & 36.50 & 6.90 & 22.10 & 4.47 & 33.50 & 6.75 \\
\hline
\end{tabular}


Table 2. The effect of roof and/or funnel and their interaction on the numbers of spiders and carabids caught by pitfall traps. Conventional pitfall traps were used as a control. Regression coefficients $(\beta), t$ and $P$ values are given. $\mathrm{N}-$ number of individuals, $\mathrm{S}-\mathrm{small}(<10 \mathrm{~mm})$, $\mathrm{L}$ - large (>10 mm), F1 - non-flying, F2 - flying possible, F3 - flying, f - forests, g - grasslands.

\begin{tabular}{|c|c|c|c|c|c|c|c|c|c|c|c|}
\hline & \multicolumn{3}{|c|}{ Roof } & \multicolumn{3}{|c|}{ Funnel } & \multicolumn{3}{|c|}{ Roof : Funnel } & \multirow{2}{*}{\multicolumn{2}{|c|}{$\mathrm{R}^{2}$}} \\
\hline & \multirow[t]{2}{*}{$\beta$} & \multirow[t]{2}{*}{$t$} & \multirow[t]{2}{*}{$P$} & \multirow[t]{2}{*}{$\beta$} & \multirow[t]{2}{*}{$t$} & \multirow[t]{2}{*}{$P$} & \multirow[t]{2}{*}{$\beta$} & \multirow[t]{2}{*}{$t$} & \multirow[t]{2}{*}{$P$} & & \\
\hline & & & & & & & & & & marginal & onditional \\
\hline \multicolumn{12}{|l|}{ Spiders } \\
\hline $\mathrm{N}$ & 0.181 & 1.535 & 0.130 & -0.047 & -0.379 & 0.705 & 0.016 & 0.094 & 0.924 & 0.002 & 0.015 \\
\hline Large $\mathrm{N}$ & 0.037 & 0.186 & 0.852 & 0.074 & 0.369 & 0.713 & -0.301 & -1.031 & 0.306 & 0.009 & 0.151 \\
\hline Small N & 0.193 & 1.606 & 0.113 & -0.058 & -0.459 & 0.647 & 0.040 & 0.236 & 0.813 & 0.003 & 0.021 \\
\hline Ground N & 0.199 & 1.641 & 0.106 & -0.026 & -0.206 & 0.837 & -0.009 & -0.051 & 0.959 & 0.002 & 0.019 \\
\hline Vegetation $\mathrm{N}$ & 0.210 & 1.689 & 0.096 & -0.266 & -1.898 & 0.062 & 0.300 & 1.645 & 0.105 & 0.033 & 0.107 \\
\hline \multicolumn{12}{|c|}{ Carabid beetles } \\
\hline $\mathrm{N}$ & -0.110 & -0.945 & 0.348 & -0.611 & -4.532 & $<0.001$ & 0.585 & 3.236 & 0.002 & 0.009 & 0.151 \\
\hline L-F1 & -0.099 & -0.689 & 0.493 & -0.749 & -4.274 & $<0.001$ & 0.584 & 2.500 & 0.015 & 0.025 & 0.233 \\
\hline L-F2 & 0.032 & 0.204 & 0.839 & -0.531 & -2.933 & 0.005 & 0.374 & 1.550 & 0.127 & 0.011 & 0.518 \\
\hline L-F3 & -0.138 & -0.689 & 0.494 & -0.971 & -3.727 & $<0.001$ & 0.780 & 2.298 & 0.025 & 0.028 & 0.535 \\
\hline S-F1 & -0.126 & -0.518 & 0.606 & -0.221 & -0.882 & 0.382 & 0.630 & 1.855 & 0.069 & 0.010 & 0.283 \\
\hline S-F2 & -0.288 & -0.980 & 0.331 & -0.575 & -1.796 & 0.078 & 0.426 & 0.931 & 0.356 & 0.020 & 0.275 \\
\hline S-F3 & -0.405 & -1.663 & 0.102 & -0.492 & -1.966 & 0.054 & 0.939 & 2.696 & 0.009 & 0.020 & 0.419 \\
\hline L-F2 (f) & 0.061 & 0.366 & 0.717 & -0.524 & -2.659 & 0.013 & 0.385 & 1.477 & 0.151 & 0.022 & 0.068 \\
\hline L-F2 (g) & -0.486 & -0.942 & 0.355 & -0.619 & -1.151 & 0.260 & -0.074 & -0.084 & 0.934 & 0.080 & 0.474 \\
\hline L-F3 (f) & -0.084 & -0.322 & 0.750 & -0.949 & -2.777 & 0.010 & 0.690 & 1.550 & 0.133 & 0.034 & 0.129 \\
\hline L-F3 (g) & -2.079 & -1.903 & 0.068 & -1.386 & -1.702 & 0.100 & 3.332 & 2.433 & 0.022 & 0.309 & 0.620 \\
\hline
\end{tabular}

difference in the total abundances of spiders or the abundance of the different functional groups (Tables 2 and S5).

The species richness of carabid beetles was also unaffected by type of trap (roof: $\mathrm{z}=-1.018, \mathrm{P}=0.309$; funnel: $\mathrm{z}=-0.652, \mathrm{P}=0.515$; funnel $\times$ roof: $\mathrm{z}=1.141, \mathrm{P}=0.254$, marg. $\mathrm{R}^{2}=0.007$, con. $\left.\mathrm{R}^{2}=0.561\right)$. The abundance of the carabid beetles caught was affected by the different types of traps (Tables 2 and S5). The total abundance of beetles was lower in funnel pitfall traps than in conventional traps. Roof alone had no effect, but the use of both roof and a funnel had a positive effect on the capture efficiency. Type of trap had no effect on the abundance of small beetles, except for the positive effect of funnel pitfall traps with a roof on the capture of the S-F3 group. Regardless of their flight ability, fewer large beetles were collected by funnel pitfall traps than by the other types of traps. In the two habitats, the type of pitfall trap had a different effect on the abundance of large carabids caught (Tables 2 and S5). In forests, funnel pitfall traps collected fewer L-F2 and L-F3 carabids, and in grasslands, traps with a funnel and a roof had positive effect on the capture of the L-F3 group.

\section{DISCUSSION}

Numerous factors bias pitfall trap catches (reviewed by Brown \& Matthews, 2016), however, this method has several favourable attributes such as low labour-requirement and simultaneous sampling at many locations. In this study, we compared the effects of different combinations of funnel and roof types of pitfall traps. In support of our hypothesis there was no bias in the capture efficiency of arthropods by funnel pitfall traps with a roof in this study. We also showed that the suitability of different types of traps depends on the target taxa (spider vs carabids) and functional group (e.g. small vs large beetles). Type of trap did not affect significantly the number of spiders caught, however, funnel pitfall traps collected fewer large beetles.
Moreover, we show, that funnel pitfall traps with roofs catch fewer small vertebrates (Table S4). Funnel pitfall traps perform better than conventional pitfall traps for several reasons. They can be more efficient in retaining invertebrates in the cups and thus collect more specimens (e.g. Vlijm et al., 1961; Baars, 1979; Obrist \& Duelli, 1996), the use of a funnel prevents the evaporation of the preservative fluid (Gurdebeke \& Maelfait, 2002), and greatly reduces catches of vertebrates (Pearce et al., 2005; Lange et al., 2011; Brown \&Matthews, 2016). However, in the present study we also found a negative effect on the number of large carabids caught. The diameter of the funnel neck was only $22 \mathrm{~mm}$ and the slope of the lateral wall of the trap was lower than in traps without funnels, allowing a greater number to escape (Cheli \& Corley, 2010; Knapp \& Ruzicka, 2012).

Our results are in accordance with Brown \& Matthews (2016), as they emphasize the benefits of using rain guards. Roofs may reduce the dilution of the preservative caused by rain and the accumulation of litter in the traps. Litter that accumulates in traps without a roof may increase the chance of escaping, which presumably decreases the catches of arthropods. Roofs may also intercept active flying beetles, thus preventing their escape. In accordance with our results, Cheli \& Corley (2010) also report no effect of roofs on the sampling of spiders. On the other hand, Siewers et al. (2014) report that the largest carabids and spiders were more frequently recorded in pitfall traps with plastic covers, than in pitfall traps with other types of cover, e.g., wire mesh. Colour of the roof has no effect on the capture efficiency of carabid beetles and spiders (Buchholz \& Hannig, 2009), however, opaque roofs may lower the sampling efficiency of species of day-active carabids (Baars, 1979; Bell et al., 2014).

Considering the random effects, we suggest that habitat has an important effect on the catching efficiency of 
different types of traps, particularly in the case of large beetles. Presumably, the higher amount of litter in forests compared to mowed grasslands, where dead plant material is removed, may increase the chance of their escaping from traps without roofs.

Compared to the other combinations, funnel pitfall traps with a roof are the most effective method for sampling. The accidental catching of vertebrates can be avoided by using funnels, and a roof may indirectly results in reducing the number of invertebrates that escape, by preventing litter from falling into the trap and retaining beetles that try to fly out of the trap. If the expectation is that a high number of large invertebrates will be caught, the diameter of the exit of the funnel has to be chosen carefully, especially if beetles are being sampled in a forest. Based on our results we emphasize that in addition to the sampling design, such as nested cross array (Perner \& Schueler, 2004) or two-circle method (Zhao et al., 2013), the use of a suitable type of trap is also important for accurately estimating the density of ground-dwelling arthropods using pitfall traps.

ACKNOWLEDGEMENTS. We thank R. Barta and S. Schwéger for their help with the field work and T. Csorba for her technical support. The research was supported by the NKFI FK 124579 project.

\section{REFERENCES}

BAARS M.A. 1979: Catches in pitfall traps in relation to mean densities of carabid beetles. - Oecologia 41: 25-46.

Babin-Fenske J. \& AnAND M. 2010: Terrestrial insect communities and the restoration of an industrially perturbed landscape: assessing success and surrogacy. - Restor. Ecol. 18: 73-84.

BAKER S.C. \& BARMUTA L.A. 2006: Evaluating spatial autocorrelation and depletion in pitfall-trap studies of environmental gradients. - J. Insect Conserv. 10: 269-276.

Bell A.J., Phillips I.D., Floate K.D., Hoemsen B.M. \& Phillips C.E. 2014: Effects of pitfall trap lid transparency and habitat structure on the catches of Carabid beetles (Coleoptera, Carabidae) in tame pasture. - Environ. Entomol. 43: 139-145.

Biró M., Czúcz B., Horváth F., Révész A., Csatári B. \& MolNÁR Z. 2013: Drivers of grassland loss in Hungary during the post-socialist transformation 1987-1999. — Landsc. Ecol. 28: 789-803.

Blake S., Foster G.N., Eyre M.D. \& Luff M.L. 1994: Effects of habit type and grassland management practices on the body size distribution of carabid beetles. - Pedobiologia 38: 502512.

Brown G.R. \& Matthews I.M. 2016: A review of extensive variation in the design of pitfall traps and a proposal for a standard pitfall trap design for monitoring ground-active arthropod biodiversity. - Ecol. Evol. 6: 3953-3964.

BRUST G.E. 1990: Direct and indirect effects of four herbicides on the activity of carabid beetles (Coleoptera, Carabidae). Pestic. Sci. 30: 309-320.

Buchar J. \& Ruzicka V. 2002: Catalogue of Spiders of the Czech Republic. Peres Publishers, Praha, 349 pp.

BuchHolz S. \& HanNig K. 2009: Do covers influence the capture efficiency of pitfall traps? - Eur. J. Entomol. 106: 667-671.

Buchiolz S., Kreuels M., Kronshage A., Terlutter H. \& Finch O.D. 2011: Bycatches of ecological field studies, bothersome or valuable? - Methods Ecol. Evol. 2: 99-102.
Cardoso P., PekÁr S., Jocqué R. \& Coddington J.A. 2011: Global patterns of guild composition and functional diversity of spiders. - PLoS ONE 6(6): e21710, 10 pp.

Cheli G.H. \& Corley J.C. 2010: Efficient sampling of grounddwelling arthropods using pitfall traps in arid steppes. - Neotrop. Entomol. 39: 912-917.

Crawley M.J. 2007: The R Book. John Wiley \& Sons, Chichester, $1076 \mathrm{pp}$.

da Silva P.M., Aguiar C.A.S., Silva I.D.F.E. \& Serrano A.R.M. 2011: Orchard and riparian habitats enhance ground dwelling beetle diversity in Mediterranean agro-forestry systems. Biodivers. Conserv. 20: 861-872.

ERnst C.M., LoBoda S. \& BuddLE C.M. 2015: Capturing northern biodiversity, diversity of arctic, subarctic and north boreal beetles and spiders are affected by trap type and habitat. - Insect Conserv. Divers. 9: 63-73.

Freude H., Harde K.W., Müller-Motzfeld G., Lohse G.A. \& Klausnitzer B. 2004: Die Käfer Mitteleuropas, Adephaga 1. Carabidae Laufkäfer. Spektrum, Munich, 521 pp.

Gurdebeke S. \& Maelfait J.P. 2002: Pitfall trapping in population genetics studies, finding the right "solution". - J. Arachnol. 30: 255-261.

Homburg K., Homburg N., Schaefer F., Schuldt A. \& Assmann T. 2014: Carabids.org - a dynamic online database of ground beetle species traits (Coleoptera, Carabidae). - Insect Conserv. Divers. 7: 195-205.

Hurka K. 1996: Carabidae of the Czech and Slovak Republics. Kabourek, Zlin, 565 pp.

Isaia M., Paschetta M., Gobbi M., Zapparoli M., Chiarle A. \& TAGLianti A.V. 2015: Stand maturity affects positively grounddwelling arthropods in a protected beech forest. - Ann. For. Sci. 72: 415-424.

Jud P. \& Schmidt-Entling M.H. 2008: Fluid type, dilution, and bitter agent influence spider preservation in pitfall traps. - Entomol. Exp. Appl. 129: 356-359.

KNAPP M. \& RuZicka J. 2012: The effect of pitfall trap construction and preservative on catch size, species richness and species composition of ground beetles Coleoptera, Carabidae. Eur. J. Entomol. 109: 419-426.

Koivula M., Kotze D.J., Hissivuori L. \& Rita H. 2003: Pitfall trap efficiency, do trap size, collecting fluid and vegetation structure matter? - Entomol. Fenn. 14: 1-14.

LANG A. 2000: The pitfalls of pitfalls, a comparison of pitfall trap catches and absolute density estimates of epigeal invertebrate predators in arable land. - J. Pest Sci. 73: 99-106.

LANGe M., Gossner M.M. \& Weisser W.W. 2011: Effect of pitfall trap type and diameter on vertebrate by-catches and ground beetle (Coleoptera, Carabidae) and spider (Araneae) sampling. - Meth. Ecol. Evol. 2: 185-190.

Longino J.T., Coddington J. \& Colwell R.K. 2002: The ant fauna of a tropical rain forest, estimating species richness three different ways. - Ecology 83: 689-702.

LuFF M.L. 1975: Some features influencing the efficiency of pitfall traps. - Oecologia 19: 345-357.

Martinson H.M. \& RAupP M.J. 2013: A meta-analysis of the effects of urbanization on ground beetle communities. - Ecosphere 4: 1-24.

Melbourne B.A. 1999: Bias in the effect of habitat structure on pitfall traps, an experimental evaluation. - Aust. J. Ecol. 24: 228-239.

Nentwig W., Blick T., Gloor D., Hänggi A. \& Kropf C. 2017: Araneae-Spiders of Europe. Ver. 08.2017. URL: http://www. araneae.unibe.ch.

New T.R. 1998: Invertebrate Surveys for Conservation. Oxford University Press, Oxford, 204 pp. 
New T.R. 1999: By-catch, ethics, and pitfall traps. - J. Insect Conserv. 3: 1-3.

ObRist M.K. \& Duelli P. 1996: Trapping efficiency of funnel-and cup-traps for epigeal arthropods. - Mitt. Schweiz. Entomol. Ges. 69: 361-369.

Pearce J.L., Schuurman D., Barber K.N., Larrivee M., Venier L.A., McKee J. \& McKenney D. 2005: Pitfall trap designs to maximize invertebrate captures and minimize captures of nontarget vertebrates. - Can. Entomol. 137: 233-250.

PeKÁr S. 2002: Differential effects of formaldehyde concentration and detergent on the catching efficiency of surface active arthropods by pitfall traps. - Pedobiologia 46: 539-547.

Perner J. \& Schueler S. 2004: Estimating the density of grounddwelling arthropods with pitfall traps using a nested-cross array. - J. Anim. Ecol. 73: 469-477.

Phillips I.D. \& CoBB T.P. 2005: Effects of habitat structure and lid transparency on pitfall catches. - Environ. Entomol. 34: 875-882.

Pihlaja M., Koivula M. \& Niemelä J. 2006: Responses of boreal carabid beetle assemblages (Coleoptera, Carabidae) to clearcutting and top-soil preparation. - Forest Ecol. Manag. 222: 182-190.

R Core Team 2016: $R$, A Language and Environment for Statistical Computing. R Foundation for Statistical Computing, Vienna. URL: https,//www.r-project.org/

Ribera I., Dolédec S., Downie I.S. \& Foster G.N. 2001: Effect of land disturbance and stress on species traits of ground beetle assemblages. - Ecology 82: 1112-1129.

Santos S.A.P., Cabanas J.E. \& Pereira J.A. 2007: Abundance and diversity of soil arthropods in olive grove ecosystem (Portugal), effect of pitfall trap type. - Eur. J. Soil Biol. 43: 77-83.

Saska P., van der Werf W., Hemerik L., Luff M.L., Hatten T.D. \& HoneK A. 2013: Temperature effects on pitfall catches of epigeal arthropods, a model and method for bias correction. $-J$. Appl. Ecol. 50: 181-189.
Schirmel J., Lenze S., Katzmann D. \& Buchrolz S. 2010: Capture efficiency of pitfall traps is highly affected by sampling interval. — Entomol. Exp. Appl. 136: 206-210.

Schmidt M.H., Clough Y., Schulz W., Westphalen A. \& TscharntKe T. 2006: Capture efficiency and preservation attributes of different fluids in pitfall traps. - J. Arachnol. 34: 159-162.

Siewers J., Schirmel J. \& Buchrolz S. 2014: The efficiency of pitfall traps as a method of sampling epigeal arthropods in litter rich forest habitats. - Eur. J. Entomol. 111: 69-74.

Sint D. \& Traugott M. 2015: Food Web Designer, a flexible tool to visalize interaction networks. - J. Pest Sci. 89: 1-5.

Southwood T.R.E. \& HeNDERson P.A. 2000: Ecological Methods. Blackwell Science, Oxford, 575 pp.

TÖlgyesi C., BÁtori Z., ERdöS L., GAllé R. \& KöRMÖCZI L. 2015: Plant diversity patterns of a Hungarian steppe-wetland mosaic in relation to grazing regime and land use history. - Tuexenia 35: $399-416$.

Vlijm L., Hartsuyker L. \& Richter C.J.J. 1961: Ecological studies on carabid beetles. - Arch. Néerl. Zool. 14: 410-422.

WARD D.F., New T.R. \& Yen A.L. 2001: Effects of pitfall trap spacing on the abundance, richness and composition of invertebrate catches. - J. Insect Conserv. 5: 47-53.

Woodcock B.A. 2005: Pitfall trapping in ecological studies. In Leather S. (ed): Insect Sampling in Forest Ecosystems. Blackwell, Oxford, pp. 37-57.

Zhao Z.H., Shi P.J., Hui C., Ouyang F., Ge F. \& Li B.L. 2013: Solving the pitfalls of pitfall trapping: a two-circle method for density estimation of ground-dwelling arthropods. - Methods Ecol. Evol. 4: 865-871.

Received February 21, 2017; revised and accepted January 3, 2018 Published online January 29, 2018

Table S1. Details of sampling. Table follows recommendation of Brown \& Matthews (2016).

\begin{tabular}{ll}
\hline Date(s) traps were set & $5-12$ May 2014; 24 Jul-1 Aug 2014; 9-20 Sep 2014 \\
Duration of each sample (in hours) & Approximately 168; 192; 264 \\
Total number of traps used & 80 \\
Total number of samples actually collected & 240 \\
The number of trap nights on which the analysis is based & 26 \\
The minimum inter-trap spacing $(\mathrm{m})$ & $8 \mathrm{~m}$ \\
The diameter of pitfall traps (at the opening) & $85 \mathrm{~mm}$ \\
The depth of the pitfall trap sample container $(\mathrm{mm})$ & 130 \\
The colour of the pitfall trap components & White roof, transparent funnel, white cup \\
The use of a rain guard & Yes \\
Height above the trap rain guard was installed $(\mathrm{mm})$ & $3-5 \mathrm{~cm}$ \\
The volume of preservative used (ml) & $500 \mathrm{ml}$ \\
The concentration and type of preservative & $50 \%$ Ethylene-glycol dissolved in water \\
The use of a funnel trap design & Yes \\
The use of a one or two cup pitfall trap design & Two cups were used \\
\hline
\end{tabular}


Table S2a. The codes for the combined category of size and flying ability of the different species of ground beetles caught in the pitfal traps. S - small $(<10 \mathrm{~mm}), \mathrm{L}$ - large $(>10 \mathrm{~mm}), \mathrm{F} 1$ - non-flying, F2 - flying possible, F3 - flying.

\begin{tabular}{|c|c|}
\hline Species & ize and flying ability \\
\hline Acupalpus luteatus (Duftschmid, 1812) & S-F3 \\
\hline Agonum duftschmidi (J. Schmidt, 1994) & S-F3 \\
\hline Agonum emarginatum (Gyllenhal, 1827) & S-F3 \\
\hline Agonum lugens (Duftschmid, 1812) & S-F3 \\
\hline Agonum permoestum (Puel, 1938) & S-F3 \\
\hline Amara aenea (De Geer, 1774) & S-F3 \\
\hline Amara communis (Panzer, 1797) & S-F3 \\
\hline Amara familiaris (Duftschmid, 1812) & S-F3 \\
\hline Amara ovata (Fabricius, 1792) & S-F3 \\
\hline Amara similata (Gyllenhal, 1810) & S-F3 \\
\hline Anthracus longicornis (Schaum, 1857) & S-F3 \\
\hline Badister bullatus (Schrank, 1798) & S-F3 \\
\hline Badister dorsiger (Duftschmid, 1812) & S-F3 \\
\hline Badister lacertosus (Sturm, 1815) & S-F3 \\
\hline Badister sodalis (Duftschmid, 1812) & S-F1 \\
\hline Badister unipustulatus (Bonelli, 1813) & S-F3 \\
\hline Calathus fuscipes (Goeze, 1777) & L-F2 \\
\hline Calathus melanocephalus (Linne, 1758) & S-F2 \\
\hline Calosoma inquisitor (Linne, 1758) & L-F3 \\
\hline Calosoma sycophanta (Linne, 1758) & L-F3 \\
\hline Carabus cancellatus (Illiger, 1798) & L-F1 \\
\hline Carabus clatratus (Linne, 1761) & L-F2 \\
\hline Carabus granulatus (Linne, 1758) & L-F2 \\
\hline Carabus violaceus (Linne, 1758) & L-F1 \\
\hline Chlaeniellus tristis (Schaller, 1783) & L-F3 \\
\hline Clivina fossor (Linne, 1758) & S-F2 \\
\hline Dyschiriodes globosus (Herbst, 1783) & S-F1 \\
\hline Harpalus caspius (Steven, 1806) & L-F2 \\
\hline Harpalus dimidiatus (P. Rossi, 1790) & L-F3 \\
\hline Harpalus luteicornis (Duftschmid, 1812) & S-F3 \\
\hline Harpalus picipennis (Duftschmid, 1812) & S-F3 \\
\hline Harpalus rubripes (Duftschmid, 1812) & L-F3 \\
\hline Harpalus serripes (Quensel in Schonherr, 1806) & L-F2 \\
\hline Harpalus tardus (Panzer, 1797) & S-F3 \\
\hline Licinus depressus (Paykull, 1790) & L-F1 \\
\hline Limodromus assimilis (Paykull, 1790) & L-F3 \\
\hline Limodromus krynickii (Sperk, 1835) & L-F3 \\
\hline Masoreus wetterhallii (Gyllenhall, 1813) & S-F2 \\
\hline Metallina lampros (Herbst, 1784) & S-F2 \\
\hline Microlestes maurus (Sturm, 1827) & S-F2 \\
\hline Microlestes minutulus (Goeze 1777) & S-F2 \\
\hline Nebria brevicollis (Fabricius, 1792) & L-F3 \\
\hline Notiophilus palustris (Duftschmid, 1812) & S-F2 \\
\hline Oodes helopioides (Fabricius, 1792) & S-F3 \\
\hline Oxypselaphus obscurus (Herbst, 1784) & S-F2 \\
\hline Panagaeus bipustulatus (Fabricius, 1775) & S-F2 \\
\hline Panagaeus cruxmajor (Linne, 1758) & S-F3 \\
\hline Paratachys bistriatus (Duftschmid, 1812) & S-F3 \\
\hline Parophonus dejeani (Csiki, 1932) & S-F2 \\
\hline Philochthus biguttatus (Fabricius, 1779) & S-F3 \\
\hline Philochthus inoptatus (Schaum, 1857) & S-F3 \\
\hline Platyderus rufus (Duftschmid, 1912) & S-F1 \\
\hline Poecilus cupreus (Linne, 1758) & L-F3 \\
\hline Poecilus versicolor (Sturm, 1824) & S-F3 \\
\hline Pseudoophonus rufipes (De Geer, 1774) & L-F3 \\
\hline Pterostichus anthracinus (Illiger, 1798) & L-F2 \\
\hline Pterostichus melanarius (Illiger, 1798) & L-F2 \\
\hline Pterostichus minor (Gyllenhal, 1827) & S-F2 \\
\hline Pterostichus niger (Schaller, 1783) & L-F2 \\
\hline Pterostichus nigrita (Paykull, 1790) & L-F2 \\
\hline Pterostichus ovoideus (Sturm, 1824) & S-F2 \\
\hline Pterostichus strenuus (Panzer, 1796) & S-F2 \\
\hline Pterostichus vernalis (Panzer, 1796) & S-F2 \\
\hline Stomis pumicatus (Panzer, 1796) & S-F1 \\
\hline Syntomus obscuroguttatus (Duftschmid, 1812) & S-F2 \\
\hline Syntomus truncatellus (Linne, 1761) & S-F2 \\
\hline Trepanes fumigatus (Duftschmid, 1812) & S-F3 \\
\hline
\end{tabular}


Table S2b. The size category and stratum preferences of the different species of spiders caught in the pitfall traps. $S-$ small $(<10$ $\mathrm{mm}), \mathrm{L}$ - large (>10 mm), G - ground-dwelling, V - vegetationdwelling.

\begin{tabular}{|c|c|c|}
\hline Species & Size & Stratum \\
\hline Agroeca cuprea (Menge, 1873) & $\mathrm{S}$ & G \\
\hline Agyneta mollis (O. P.-Cambridge, 1871) & $\mathrm{S}$ & G \\
\hline Agyneta rurestris (C. L. Koch, 1836) & $\mathrm{s}$ & G \\
\hline Allagelana gracilens (C. L. Koch, 1841) & $\mathrm{S}$ & G \\
\hline Alopecosa pulverulenta (Clerck, 1757) & $\mathrm{s}$ & G \\
\hline Altella lucida (Simon, 1874) & $\mathrm{S}$ & V \\
\hline Arctosa leopardus (Sundevall, 1833) & S & G \\
\hline Arctosa lutetiana (Simon, 1876) & $\mathrm{S}$ & G \\
\hline Asagena phalerata (Panzer, 1801) & S & G \\
\hline Aulonia albimana (Walckenaer, 1805) & $\mathrm{s}$ & G \\
\hline Ceratinella brevis (Wider, 1834) & $\mathrm{s}$ & G \\
\hline Ceratinella scabrosa (O. P.-Cambridge, 1871) & $\mathrm{S}$ & G \\
\hline Clubiona lutescens (Westring, 1851) & $\mathrm{S}$ & $\mathrm{V}$ \\
\hline Clubiona pseudoneglecta (Wunderlich, 1994) & $\mathrm{S}$ & V \\
\hline Clubiona subtilis (L. Koch, 1867) & S & V \\
\hline Clubiona terrestris (Westring, 1851) & $\mathrm{S}$ & G \\
\hline Diplocephalus picinus (Blackwall, 1841) & $\mathrm{S}$ & G \\
\hline Dolomedes fimbriatus (Clerck, 1757) & L & $\mathrm{V}$ \\
\hline Drassodes pubescens (Thorell, 1856) & $\mathrm{s}$ & G \\
\hline Drasyllus praeficus (L. Koch, 1866) & $\mathrm{S}$ & G \\
\hline Drassyllus pusillus (C. L. Koch, 1833) & $\mathrm{S}$ & G \\
\hline Enoplognatha thoracica (Hahn, 1833) & $\mathrm{S}$ & G \\
\hline Euophrys frontalis (Walckenaer, 1802) & $\mathrm{S}$ & G \\
\hline Euryopis flavomaculata (C. L. Koch, 1836) & $\mathrm{s}$ & G \\
\hline Euryopis quinqueguttata (Thorell, 1875) & $\mathrm{s}$ & G \\
\hline Evarcha arcuata (Clerck, 1757) & $\mathrm{S}$ & $\mathrm{V}$ \\
\hline Evarcha falcata (Clerck, 1757) & $\mathrm{S}$ & $\mathrm{V}$ \\
\hline Gibbaranea gibbosa (Walckenaer, 1802) & $\mathrm{S}$ & $\mathrm{V}$ \\
\hline Glyphesis taoplesius (Wunderlich, 1969) & $\mathrm{S}$ & G \\
\hline Gongylidiellum murcidum (Simon, 1884) & $\mathrm{s}$ & G \\
\hline Hahnia pusilla (C. L. Koch, 1841) & $\mathrm{S}$ & G \\
\hline Haplodrassus minor (O. P.-Cambridge, 1879) & $\mathrm{s}$ & G \\
\hline Haplodrassus signifer (C. L. Koch, 1839) & $\mathrm{S}$ & G \\
\hline Haplodrassus silvestris (Blackwall, 1833) & $\mathrm{S}$ & G \\
\hline Hogna radiata (Latreille, 1817) & $\mathrm{L}$ & G \\
\hline Hypsosinga sanguinea (C. L. Koch, 1844) & $\mathrm{S}$ & $\mathrm{V}$ \\
\hline Lasaeola prona (Menge, 1868) & $\mathrm{S}$ & G \\
\hline Linyphia hortensis (Sundevall, 1830) & $\mathrm{S}$ & $\mathrm{V}$ \\
\hline Liocranoeca striata (Kulczyński, 1882) & $\mathrm{S}$ & G \\
\hline Maso sundevalli (Westring, 1851) & $\mathrm{s}$ & $\mathrm{V}$ \\
\hline Micaria pulicaria (Sundevall, 1831) & $\mathrm{s}$ & G \\
\hline Microneta viaria (Blackwall, 1841) & $\mathrm{S}$ & G \\
\hline Neon reticulatus (Blackwall, 1853) & $\mathrm{S}$ & G \\
\hline Neriene clathrata (Sundevall, 1830) & $\mathrm{S}$ & $\mathrm{V}$ \\
\hline Oedothorax apicatus (Blackwall, 1850) & $\mathrm{s}$ & G \\
\hline Ozyptila claveata (Walckenaer, 1837) & $\mathrm{S}$ & G \\
\hline Ozyptila praticola (C. L. Koch, 1837) & $\mathrm{S}$ & G \\
\hline Ozyptila pullata (Thorell, 1875) & $\mathrm{s}$ & G \\
\hline Ozyptila scabricula (Westring, 1851) & $\mathrm{S}$ & G \\
\hline Ozyptila simplex (O. P. -Cambridge, 1862) & $\mathrm{S}$ & G \\
\hline Ozyptila trux (Blackwall, 1846) & $\mathrm{S}$ & G \\
\hline Pachygnatha degeeri (Sundevall, 1830) & $\mathrm{S}$ & G \\
\hline Pachygnatha listeri (Sundevall, 1830) & $\mathrm{S}$ & G \\
\hline Pardosa agrestis (Westring, 1861) & $\mathrm{s}$ & G \\
\hline Pardosa alacris (C. L. Koch, 1833) & $\mathrm{S}$ & G \\
\hline Pardosa lugubris (Walckenaer, 1802) & $\mathrm{S}$ & G \\
\hline Pardosa palustris (Linnaeus, 1758) & S & G \\
\hline Pardosa prativaga (L. Koch, 1870) & $\mathrm{S}$ & G \\
\hline Pardosa proxima (C. L. Koch, 1847) & $\mathrm{S}$ & G \\
\hline Pardosa pullata (Clerck, 1757) & $\mathrm{s}$ & G \\
\hline Phlegra fasciata (Hahn, 1826) & $\mathrm{S}$ & G \\
\hline Phrurolithus festivus (C. L. Koch, 1835) & $\mathrm{S}$ & G \\
\hline Phrurolithus minimus (C. L. Koch, 1839) & $\mathrm{S}$ & G \\
\hline Pirata piraticus (Clerck, 1757) & $\mathrm{S}$ & G \\
\hline Pirata uliginosus (Thorell, 1856) & $\mathrm{S}$ & G \\
\hline Piratula hygrophila (Thorell, 1872) & $\mathrm{s}$ & G \\
\hline Piratula latitans (Blackwall, 1841) & $\mathrm{S}$ & G \\
\hline
\end{tabular}

Table S2b (continued).

\begin{tabular}{|c|c|c|}
\hline Species & Size & Stratum \\
\hline Pisaura mirabilis (Clerck, 1757) & $\mathrm{L}$ & V \\
\hline Pocadicnemis juncea (Locket \& Millidge, 1953) & S & G \\
\hline Prinerigone vagans (Audouin, 1826) & $\mathrm{s}$ & G \\
\hline Robertus lividus (Blackwall, 1836) & S & G \\
\hline Silometopus elegans (O. P.-Cambridge, 1872) & S & G \\
\hline Silometopus incurvatus (O. P.-Cambridge, 1873) & S & G \\
\hline Styloctetor stativus (Simon, 1881) & S & G \\
\hline Syedra gracilis (Menge, 1869) & S & G \\
\hline Talavera aequipes (O. P.-Cambridge, 1871) & S & G \\
\hline Tapinocyba insecta (L. Koch, 1869) & S & G \\
\hline Tenuiphantes flavipes (Blackwall, 1854) & S & G \\
\hline Tenuiphantes tenuis (Blackwall, 1852) & S & G \\
\hline Thanatus arenarius (L. Koch, 1872) & S & G \\
\hline Thanatus formicinus (Clerck, 1757) & S & G \\
\hline Tmarus piger (Walckenaer, 1802) & S & V \\
\hline Trachyzelotes pedestris (C. L. Koch, 1837) & S & G \\
\hline Trichoncus hackmani (Millidge, 1955) & S & G \\
\hline Trochosa ruricola (De Geer, 1778) & $\mathrm{L}$ & G \\
\hline Trochosa terricola (Thorell, 1856) & $\mathrm{L}$ & G \\
\hline Walckenaeria alticeps (Denis, 1952) & S & G \\
\hline Walckenaeria dysderoides (Wider, 1834) & S & G \\
\hline Walckenaeria vigilax (Blackwall, 1853) & $\mathrm{S}$ & G \\
\hline Xerolycosa miniata (C. L. Koch, 1834) & S & G \\
\hline Xysticus erraticus (Blackwall, 1834) & S & V \\
\hline Xysticus kochi (Thorell, 1872) & S & G \\
\hline Xysticus lineatus (Westring, 1851) & S & G \\
\hline Xysticus luctator (L. Koch, 1870) & S & G \\
\hline Xysticus robustus (Hahn, 1832) & S & G \\
\hline Zelotes apricorum (L. Koch, 1876) & S & G \\
\hline Zelotes electus (C. L. Koch, 1839) & S & G \\
\hline Zelotes latreillei (Simon, 1878) & S & G \\
\hline Zora armillata (Simon, 1878) & S & G \\
\hline Zora spinimana (Sundevall, 1833) & S & G \\
\hline
\end{tabular}




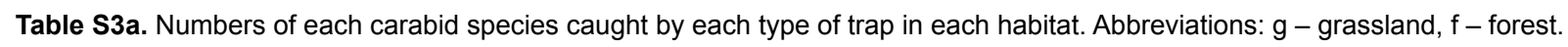

\begin{tabular}{|c|c|c|c|c|c|c|c|c|}
\hline \multirow{2}{*}{$\begin{array}{l}\text { Trap type } \\
\text { Habitat }\end{array}$} & \multicolumn{2}{|c|}{$\begin{array}{l}\text { conv. } \\
\text { pitfall }\end{array}$} & \multicolumn{2}{|c|}{$\begin{array}{l}\text { pitfall } \\
+ \text { roof }\end{array}$} & \multicolumn{2}{|c|}{$\begin{array}{c}\text { funnel } \\
\text { pitfall }\end{array}$} & \multicolumn{2}{|c|}{$\begin{array}{c}\text { funnel pitfall } \\
+ \text { roof }\end{array}$} \\
\hline & $\mathrm{g}$ & f & $g$ & f & $g$ & f & $\mathrm{g}$ & $f$ \\
\hline Acupalpus luteatus (Duftschmid, 1812) & 0 & 0 & 1 & 0 & 0 & 0 & 0 & 0 \\
\hline Agonum duftschmidi (J. Schmidt, 1994) & 4 & 32 & 0 & 22 & 0 & 19 & 0 & 37 \\
\hline Agonum emarginatum (Gyllenhal, 1827) & 1 & 8 & 0 & 2 & 0 & 1 & 1 & 1 \\
\hline Agonum lugens (Duftschmid, 1812) & 0 & 1 & 0 & 0 & 0 & 0 & 0 & 0 \\
\hline Agonum permoestum (Puel, 1938) & 0 & 0 & 0 & 8 & 0 & 2 & 0 & 2 \\
\hline Amara aenea (De Geer, 1774) & 4 & 0 & 0 & 0 & 2 & 0 & 0 & 0 \\
\hline Amara communis (Panzer, 1797) & 4 & 0 & 0 & 0 & 2 & 0 & 2 & 0 \\
\hline Amara familiaris (Duftschmid, 1812) & 0 & 0 & 0 & 0 & 1 & 0 & 0 & 0 \\
\hline Amara ovata (Fabricius, 1792) & 0 & 0 & 0 & 0 & 0 & 1 & 0 & 0 \\
\hline Amara similata (Gyllenhal, 1810) & 0 & 0 & 0 & 0 & 0 & 0 & 0 & 1 \\
\hline Anthracus longicornis (Schaum, 1857) & 0 & 1 & 0 & 1 & 0 & 2 & 0 & 1 \\
\hline Badister bullatus (Schrank, 1798) & 0 & 0 & 0 & 2 & 0 & 2 & 2 & 0 \\
\hline Badister dorsiger (Duftschmid, 1812) & 0 & 1 & 0 & 0 & 0 & 2 & 0 & 3 \\
\hline Badister lacertosus (Sturm, 1815) & 0 & 0 & 0 & 1 & 0 & 1 & 0 & 0 \\
\hline Badister sodalis (Duftschmid, 1812) & 0 & 0 & 0 & 0 & 0 & 0 & 0 & 2 \\
\hline Badister unipustulatus (Bonelli, 1813) & 0 & 2 & 0 & 1 & 0 & 1 & 0 & 0 \\
\hline Calathus fuscipes (Goeze, 1777) & 0 & 0 & 0 & 0 & 0 & 1 & 0 & 0 \\
\hline Calathus melanocephalus (Linne, 1758) & 1 & 0 & 0 & 0 & 0 & 0 & 0 & 0 \\
\hline Calosoma inquisitor (Linne, 1758) & 0 & 4 & 0 & 2 & 0 & 5 & 0 & 3 \\
\hline Calosoma sycophanta (Linne, 1758) & 4 & 0 & 11 & 0 & 0 & 0 & 1 & 0 \\
\hline Carabus cancellatus (Illiger, 1798) & 6 & 0 & 2 & 0 & 4 & 0 & 1 & 0 \\
\hline Carabus clatratus (Linne, 1761) & 1 & 0 & 0 & 0 & 0 & 0 & 0 & 0 \\
\hline Carabus granulatus (Linne, 1758) & 0 & 1 & 0 & 0 & 0 & 1 & 0 & 0 \\
\hline Carabus violaceus (Linne, 1758) & 0 & 0 & 0 & 1 & 0 & 0 & 0 & 0 \\
\hline Chlaeniellus tristis (Schaller, 1783) & 93 & 167 & 67 & 169 & 29 & 89 & 44 & 154 \\
\hline Clivina fossor (Linne, 1758) & 0 & 1 & 0 & 0 & 0 & 1 & 0 & 0 \\
\hline Dyschiriodes globosus (Herbst, 1783) & 2 & 135 & 0 & 130 & 1 & 72 & 0 & 117 \\
\hline Harpalus caspius (Steven, 1806) & 11 & 2 & 5 & 6 & 6 & 3 & 12 & 1 \\
\hline Harpalus dimidiatus (P. Rossi, 1790) & 0 & 0 & 0 & 0 & 0 & 1 & 0 & 0 \\
\hline Harpalus luteicornis (Duftschmid, 1812) & 0 & 0 & 0 & 0 & 0 & 1 & 0 & 0 \\
\hline Harpalus picipennis (Duftschmid, 1812) & 11 & 90 & 13 & 74 & 11 & 69 & 26 & 105 \\
\hline Harpalus rubripes (Duftschmid, 1812) & 0 & 0 & 0 & 0 & 0 & 0 & 2 & 0 \\
\hline Harpalus serripes (Quensel in Schonherr, 1806) & 0 & 0 & 0 & 0 & 0 & 0 & 1 & 0 \\
\hline Harpalus tardus (Panzer, 1797) & 0 & 0 & 1 & 0 & 0 & 0 & 0 & 0 \\
\hline Licinus depressus (Paykull, 1790) & 0 & 0 & 0 & 0 & 0 & 0 & 1 & 1 \\
\hline Limodromus assimilis (Paykull, 1790) & 0 & 0 & 0 & 0 & 0 & 0 & 2 & 0 \\
\hline Limodromus krynickii (Sperk, 1835) & 0 & 1 & 0 & 0 & 0 & 0 & 0 & 0 \\
\hline Masoreus wetterhallii (Gyllenhall, 1813) & 0 & 0 & 0 & 1 & 0 & 0 & 1 & 0 \\
\hline Metallina lampros (Herbst, 1784) & 1 & 1 & 2 & 0 & 0 & 3 & 0 & 0 \\
\hline Microlestes maurus (Sturm, 1827) & 0 & 0 & 2 & 0 & 0 & 0 & 1 & 0 \\
\hline Microlestes minutulus (Goeze 1777) & 5 & 0 & 8 & 0 & 4 & 0 & 0 & 0 \\
\hline Nebria brevicollis (Fabricius, 1792) & 2 & 0 & 0 & 0 & 1 & 0 & 0 & 0 \\
\hline Notiophilus palustris (Duftschmid, 1812) & 0 & 5 & 0 & 24 & 0 & 6 & 0 & 10 \\
\hline Oodes helopioides (Fabricius, 1792) & 0 & 2 & 0 & 1 & 0 & 4 & 0 & 0 \\
\hline Oxypselaphus obscurus (Herbst, 1784) & 1 & 4 & 0 & 2 & 0 & 1 & 0 & 0 \\
\hline Panagaeus bipustulatus (Fabricius, 1775) & 3 & 23 & 0 & 2 & 0 & 4 & 0 & 10 \\
\hline Panagaeus cruxmajor (Linne, 1758) & 1 & 0 & 1 & 0 & 0 & 0 & 0 & 1 \\
\hline Paratachys bistriatus (Duftschmid, 1812) & 0 & 0 & 0 & 0 & 0 & 0 & 0 & 4 \\
\hline Parophonus dejeani (Csiki, 1932) & 1 & 0 & 1 & 0 & 0 & 1 & 0 & 0 \\
\hline Philochthus biguttatus (Fabricius, 1779) & 0 & 0 & 0 & 0 & 0 & 0 & 1 & 0 \\
\hline Philochthus inoptatus (Schaum, 1857) & 0 & 0 & 0 & 0 & 0 & 0 & 0 & 2 \\
\hline Platyderus rufus (Duftschmid, 1912) & 0 & 0 & 0 & 0 & 0 & 0 & 0 & 2 \\
\hline Poecilus cupreus (Linne, 1758) & 6 & 67 & 0 & 53 & 0 & 31 & 0 & 42 \\
\hline Poecilus versicolor (Sturm, 1824) & 2 & 50 & 1 & 36 & 1 & 9 & 3 & 34 \\
\hline Pseudoophonus rufipes (De Geer, 1774) & 0 & 1 & 0 & 1 & 0 & 0 & 1 & 11 \\
\hline Pterostichus anthracinus (Illiger, 1798) & 0 & 0 & 0 & 0 & 1 & 0 & 1 & 0 \\
\hline Pterostichus melanarius (Illiger, 1798) & 4 & 36 & 6 & 45 & 2 & 25 & 1 & 40 \\
\hline Pterostichus minor (Gyllenhal, 1827) & 1 & 2 & 0 & 7 & 0 & 4 & 0 & 1 \\
\hline Pterostichus niger (Schaller, 1783) & 0 & 0 & 0 & 2 & 0 & 1 & 0 & 1 \\
\hline Pterostichus nigrita (Paykull, 1790) & 0 & 1 & 0 & 3 & 0 & 0 & 0 & 3 \\
\hline Pterostichus ovoideus (Sturm, 1824) & 0 & 0 & 0 & 0 & 0 & 1 & 0 & 0 \\
\hline Pterostichus strenuus (Panzer, 1796) & 0 & 1 & 0 & 1 & 0 & 2 & 0 & 0 \\
\hline Pterostichus vernalis (Panzer, 1796) & 0 & 3 & 0 & 3 & 0 & 1 & 0 & 6 \\
\hline Stomis pumicatus (Panzer, 1796) & 0 & 3 & 0 & 1 & 0 & 6 & 0 & 3 \\
\hline Syntomus obscuroguttatus (Duftschmid, 1812) & 0 & 0 & 0 & 2 & 0 & 1 & 0 & 1 \\
\hline Syntomus truncatellus (Linne, 1761) & 0 & 0 & 0 & 1 & 0 & 0 & 0 & 2 \\
\hline Trepanes fumigatus (Duftschmid, 1812) & 1 & 0 & 5 & 0 & 3 & 0 & 6 & 0 \\
\hline
\end{tabular}


Table S3b. Numbers of each spider species caught by each type of trap in each habitat. Abbreviations: $g$ - grassland, $f-f o r e s t$.

\begin{tabular}{|c|c|c|c|c|c|c|c|c|}
\hline \multirow{2}{*}{$\begin{array}{l}\text { Trap type } \\
\text { Habitat }\end{array}$} & \multicolumn{2}{|c|}{$\begin{array}{l}\text { conv. } \\
\text { pitfall }\end{array}$} & \multicolumn{2}{|c|}{$\begin{array}{l}\text { pitfall } \\
+ \text { roof }\end{array}$} & \multicolumn{2}{|c|}{$\begin{array}{l}\text { funnel } \\
\text { pitfall }\end{array}$} & \multicolumn{2}{|c|}{$\begin{array}{l}\text { funnel pitfall } \\
+ \text { roof }\end{array}$} \\
\hline & g & $f$ & g & $f$ & g & $f$ & $\mathrm{~g}$ & f \\
\hline Agroeca cuprea (Menge, 1873) & 1 & 0 & 1 & 3 & 1 & 2 & 1 & 1 \\
\hline Agyneta mollis (O. P.-Cambridge, 1871) & 2 & 0 & 1 & 0 & 1 & 0 & 3 & 0 \\
\hline Agyneta rurestris (C. L. Koch, 1836) & 8 & 0 & 16 & 0 & 6 & 0 & 16 & 0 \\
\hline Allagelena gracilens (C. L. Koch, 1841) & 0 & 0 & 0 & 0 & 1 & 0 & 0 & 0 \\
\hline Alopecosa pulverulenta (Clerck, 1757) & 6 & 0 & 11 & 0 & 8 & 0 & 6 & 1 \\
\hline Altella lucida (Simon, 1874) & 16 & 0 & 15 & 0 & 13 & 0 & 22 & 0 \\
\hline Arctosa leopardus (Sundevall, 1833) & 1 & 0 & 0 & 0 & 0 & 0 & 0 & 0 \\
\hline Arctosa lutetiana (Simon, 1876) & 22 & 19 & 27 & 27 & 15 & 22 & 23 & 24 \\
\hline Asagena phalerata (Panzer, 1801) & 2 & 0 & 0 & 0 & 2 & 0 & 0 & 0 \\
\hline Aulonia albimana (Walckenaer, 1805) & 49 & 0 & 106 & 0 & 28 & 0 & 84 & 0 \\
\hline Ceratinella brevis (Wider, 1834) & 1 & 0 & 0 & 0 & 0 & 0 & 0 & 0 \\
\hline Ceratinella scabrosa (O. P.-Cambridge, 1871) & 0 & 2 & 0 & 0 & 0 & 3 & 1 & 2 \\
\hline Clubiona lutescens (Westring, 1851) & 0 & 0 & 0 & 1 & 0 & 0 & 0 & 0 \\
\hline Clubiona pseudoneglecta (Wunderlich, 1994) & 1 & 0 & 1 & 0 & 0 & 0 & 1 & 0 \\
\hline Clubiona subtilis (L. Koch, 1867) & 0 & 0 & 1 & 0 & 0 & 0 & 0 & 0 \\
\hline Clubiona terrestris (Westring, 1851) & 0 & 0 & 0 & 0 & 0 & 0 & 0 & 1 \\
\hline Diplocephalus picinus (Blackwall, 1841) & 0 & 15 & 0 & 10 & 0 & 48 & 1 & 42 \\
\hline Dolomedes fimbriatus (Clerck, 1757) & 1 & 0 & 0 & 1 & 0 & 0 & 0 & 0 \\
\hline Drassodes pubescens (Thorell, 1856) & 0 & 0 & 0 & 0 & 1 & 0 & 3 & 0 \\
\hline Drassyllus praeficus (L. Koch, 1866) & 1 & 0 & 2 & 0 & 1 & 0 & 0 & 0 \\
\hline Drassyllus pusillus (C. L. Koch, 1833) & 7 & 0 & 2 & 0 & 4 & 0 & 1 & 0 \\
\hline Enoplognatha thoracica (Hahn, 1833) & 0 & 3 & 0 & 2 & 1 & 9 & 0 & 4 \\
\hline Euophrys frontalis (Walckenaer, 1802) & 0 & 0 & 6 & 0 & 1 & 0 & 1 & 0 \\
\hline Euryopis flavomaculata (C. L. Koch, 1836) & 1 & 3 & 3 & 4 & 0 & 1 & 1 & 3 \\
\hline Euryopis quinqueguttata (Thorell, 1875) & 1 & 0 & 1 & 0 & 4 & 0 & 3 & 0 \\
\hline Evarcha arcuata (Clerck, 1757) & 2 & 0 & 0 & 0 & 0 & 0 & 0 & 0 \\
\hline Evarcha falcata (Clerck, 1757) & 0 & 0 & 0 & 1 & 0 & 0 & 0 & 0 \\
\hline Gibbaranea gibbosa (Walckenaer, 1802) & 0 & 1 & 0 & 0 & 0 & 0 & 0 & 0 \\
\hline Glyphesis taoplesius (Wunderlich, 1969) & 1 & 5 & 1 & 3 & 1 & 17 & 3 & 27 \\
\hline Gongylidiellum murcidum (Simon, 1884) & 0 & 0 & 0 & 0 & 1 & 1 & 0 & 0 \\
\hline Hahnia pusilla (C. L. Koch, 1841) & 6 & 1 & 1 & 0 & 1 & 2 & 3 & 0 \\
\hline Haplodrassus minor (O. P.-Cambridge, 1879) & 1 & 0 & 2 & 0 & 1 & 0 & 0 & 0 \\
\hline Haplodrassus signifer (C. L. Koch, 1839) & 0 & 0 & 0 & 1 & 2 & 0 & 0 & 0 \\
\hline Haplodrassus silvestris (Blackwall, 1833) & 0 & 5 & 0 & 0 & 0 & 1 & 0 & 2 \\
\hline Hogna radiata (Latreille, 1817) & 6 & 0 & 8 & 0 & 5 & 0 & 1 & 0 \\
\hline Hypsosinga sanguinea (C. L. Koch, 1844) & 0 & 0 & 1 & 0 & 0 & 0 & 0 & 0 \\
\hline Lasaeola prona (Menge, 1868) & 0 & 0 & 1 & 0 & 0 & 0 & 0 & 0 \\
\hline Linyphia hortensis (Sundevall, 1830) & 0 & 0 & 0 & 0 & 0 & 0 & 0 & 2 \\
\hline Liocranoeca striata (Kulczyński, 1882) & 6 & 20 & 7 & 31 & 1 & 30 & 5 & 27 \\
\hline Maso sundevalli (Westring, 1851) & 0 & 1 & 0 & 0 & 0 & 1 & 0 & 1 \\
\hline Micaria pulicaria (Sundevall, 1831) & 1 & 0 & 2 & 0 & 0 & 0 & 2 & 0 \\
\hline Microneta viaria (Blackwall, 1841) & 0 & 1 & 0 & 0 & 0 & 0 & 0 & 0 \\
\hline Neon reticulatus (Blackwall, 1853) & 0 & 1 & 0 & 0 & 0 & 0 & 0 & 0 \\
\hline Neriene clathrata (Sundevall, 1830) & 0 & 0 & 0 & 3 & 0 & 2 & 0 & 1 \\
\hline Oedothorax apicatus (Blackwall, 1850) & 0 & 0 & 0 & 1 & 0 & 0 & 0 & 0 \\
\hline Ozyptila claveata (Walckenaer, 1837) & 1 & 0 & 2 & 0 & 2 & 0 & 4 & 0 \\
\hline Ozyptila praticola (C. L. Koch, 1837) & 0 & 56 & 0 & 26 & 0 & 48 & 0 & 49 \\
\hline Ozyptila pullata (Thorell, 1875) & 3 & 0 & 8 & 0 & 1 & 0 & 1 & 0 \\
\hline Ozyptila scabricula (Westring, 1851) & 0 & 0 & 2 & 0 & 0 & 0 & 1 & 0 \\
\hline Ozyptila simplex (O. P.-Cambridge, 1862) & 0 & 0 & 1 & 0 & 0 & 0 & 0 & 0 \\
\hline Ozyptila trux (Blackwall, 1846) & 1 & 0 & 10 & 0 & 2 & 0 & 0 & 0 \\
\hline Pachygnatha degeeri (Sundevall, 1830) & 8 & 0 & 11 & 0 & 4 & 0 & 9 & 0 \\
\hline Pachygnatha listeri (Sundevall, 1830) & 0 & 4 & 0 & 2 & 0 & 5 & 0 & 3 \\
\hline Pardosa agrestis (Westring, 1861) & 0 & 0 & 2 & 0 & 0 & 0 & 0 & 0 \\
\hline Pardosa alacris (C. L. Koch, 1833) & 0 & 5 & 0 & 3 & 1 & 7 & 0 & 4 \\
\hline Pardosa lugubris (Walckenaer, 1802) & 4 & 49 & 4 & 40 & 4 & 55 & 4 & 32 \\
\hline Pardosa palustris (Linnaeus, 1758) & 0 & 0 & 0 & 0 & 0 & 0 & 2 & 0 \\
\hline Pardosa prativaga (L. Koch, 1870) & 10 & 0 & 7 & 0 & 3 & 0 & 6 & 0 \\
\hline Pardosa proxima (C. L. Koch, 1847) & 1 & 0 & 0 & 0 & 0 & 0 & 6 & 0 \\
\hline Pardosa pullata (Clerck, 1757) & 14 & 1 & 8 & 0 & 5 & 0 & 9 & 0 \\
\hline Phlegra fasciata (Hahn, 1826) & 1 & 0 & 0 & 0 & 0 & 0 & 0 & 0 \\
\hline Phrurolithus festivus (C. L. Koch, 1835) & 0 & 0 & 0 & 1 & 0 & 0 & 2 & 3 \\
\hline Phrurolithus minimus (C. L. Koch, 1839) & 0 & 1 & 2 & 0 & 1 & 1 & 5 & 0 \\
\hline Pirata piraticus (Clerck, 1757) & 1 & 0 & 0 & 0 & 0 & 0 & 0 & 0 \\
\hline Pirata uliginosus (Thorell, 1856) & 0 & 4 & 0 & 9 & 0 & 13 & 1 & 2 \\
\hline Piratula hygrophila (Thorell, 1872) & 0 & 134 & 0 & 206 & 1 & 111 & 0 & 156 \\
\hline Piratula latitans (Blackwall, 1841) & 7 & 6 & 6 & 9 & 5 & 3 & 0 & 4 \\
\hline Pisaura mirabilis (Clerck, 1757) & 10 & 2 & 2 & 3 & 3 & 1 & 2 & 0 \\
\hline
\end{tabular}


Table S3b (continued).

\begin{tabular}{|c|c|c|c|c|c|c|c|c|}
\hline \multirow{2}{*}{$\begin{array}{l}\text { Trap type } \\
\text { Habitat }\end{array}$} & \multicolumn{2}{|c|}{$\begin{array}{l}\text { conv. } \\
\text { pitfall }\end{array}$} & \multicolumn{2}{|c|}{$\begin{array}{l}\text { pitfall } \\
+ \text { roof }\end{array}$} & \multicolumn{2}{|c|}{$\begin{array}{l}\text { funnel } \\
\text { pitfall }\end{array}$} & \multicolumn{2}{|c|}{$\begin{array}{c}\text { funnel pitfall } \\
+ \text { roof }\end{array}$} \\
\hline & $g$ & $f$ & $\mathrm{~g}$ & $f$ & $\mathrm{~g}$ & $f$ & $\mathrm{~g}$ & $f$ \\
\hline Pocadicnemis juncea (Locket \& Millidge, 1953) & 1 & 0 & 1 & 0 & 0 & 1 & 2 & 3 \\
\hline Prinerigone vagans (Audouin, 1826) & 0 & 0 & 0 & 0 & 0 & 1 & 0 & 0 \\
\hline Robertus lividus (Blackwall, 1836) & 0 & 3 & 0 & 0 & 0 & 0 & 0 & 0 \\
\hline Silometopus elegans (O. P.-Cambridge, 1872) & 0 & 1 & 0 & 0 & 0 & 3 & 0 & 3 \\
\hline Silometopus incurvatus (O. P.-Cambridge, 1873) & 0 & 0 & 0 & 0 & 0 & 1 & 0 & 0 \\
\hline Styloctetor stativus (Simon, 1881) & 5 & 0 & 4 & 0 & 6 & 0 & 11 & 0 \\
\hline Syedra gracilis (Menge, 1869) & 3 & 0 & 3 & 0 & 1 & 0 & 4 & 0 \\
\hline Talavera aequipes (O. P.-Cambridge, 1871) & 1 & 0 & 0 & 0 & 0 & 0 & 0 & 0 \\
\hline Tapinocyba insecta (L. Koch, 1869) & 0 & 0 & 0 & 1 & 0 & 0 & 0 & 0 \\
\hline Tenuiphantes flavipes (Blackwall, 1854) & 0 & 2 & 0 & 1 & 0 & 1 & 0 & 0 \\
\hline Tenuiphantes tenuis (Blackwall, 1852) & 0 & 1 & 0 & 0 & 0 & 1 & 0 & 0 \\
\hline Thanatus arenarius (L. Koch, 1872) & 2 & 0 & 2 & 0 & 1 & 0 & 0 & 0 \\
\hline Thanatus formicinus (Clerck, 1757) & 0 & 0 & 0 & 0 & 0 & 0 & 2 & 0 \\
\hline Tmarus piger (Walckenaer, 1802) & 0 & 1 & 0 & 0 & 0 & 0 & 0 & 0 \\
\hline Trachyzelotes pedestris (C. L. Koch, 1837) & 2 & 5 & 5 & 5 & 3 & 8 & 6 & 1 \\
\hline Trichoncus hackmani (Millidge, 1955) & 1 & 2 & 3 & 0 & 3 & 1 & 7 & 0 \\
\hline Trochosa ruricola (De Geer, 1778) & 9 & 4 & 11 & 12 & 15 & 15 & 16 & 10 \\
\hline Trochosa terricola (Thorell, 1856) & 11 & 9 & 13 & 4 & 11 & 6 & 11 & 3 \\
\hline Walckenaeria alticeps (Denis, 1952) & 0 & 3 & 0 & 1 & 0 & 1 & 0 & 3 \\
\hline Walckenaeria dysderoides (Wider, 1834) & 0 & 0 & 0 & 0 & 0 & 1 & 0 & 1 \\
\hline Walckenaeria vigilax (Blackwall, 1853) & 0 & 0 & 0 & 0 & 0 & 0 & 0 & 1 \\
\hline Xerolycosa miniata (C. L. Koch, 1834) & 0 & 0 & 2 & 0 & 0 & 0 & 0 & 0 \\
\hline Xysticus erraticus (Blackwall, 1834) & 0 & 0 & 0 & 0 & 0 & 0 & 2 & 0 \\
\hline Xysticus kochi (Thorell, 1872) & 6 & 0 & 4 & 0 & 5 & 0 & 7 & 0 \\
\hline Xysticus lineatus (Westring, 1851) & 7 & 0 & 16 & 0 & 8 & 0 & 19 & 0 \\
\hline Xysticus luctator (L. Koch, 1870) & 3 & 12 & 0 & 12 & 2 & 6 & 1 & 8 \\
\hline Xysticus robustus (Hahn, 1832) & 1 & 0 & 0 & 0 & 0 & 0 & 0 & 0 \\
\hline Zelotes apricorum (L. Koch, 1876) & 0 & 1 & 1 & 2 & 0 & 2 & 1 & 3 \\
\hline Zelotes electus (C. L. Koch, 1839) & 3 & 0 & 3 & 0 & 0 & 0 & 2 & 0 \\
\hline Zelotes latreillei (Simon, 1878) & 0 & 0 & 2 & 0 & 0 & 0 & 0 & 0 \\
\hline Zora armillata (Simon, 1878) & 1 & 0 & 0 & 0 & 0 & 0 & 0 & 0 \\
\hline Zora spinimana (Sundevall, 1833) & 0 & 4 & 0 & 0 & 0 & 0 & 0 & 1 \\
\hline
\end{tabular}

Table S4. Number of vertebrates caught in each type of trap in each habitat. Abbreviation: S - small.

\begin{tabular}{|c|c|c|c|c|c|c|c|c|}
\hline & \multicolumn{4}{|c|}{ Grassland } & \multicolumn{4}{|c|}{ Forest } \\
\hline & $\begin{array}{l}\text { conv. } \\
\text { pitfall }\end{array}$ & $\begin{array}{l}\text { pitfall } \\
+ \text { roof }\end{array}$ & $\begin{array}{c}\text { funnel } \\
\text { pitfall }\end{array}$ & $\begin{array}{c}\text { funnel pitfall } \\
+ \text { roof }\end{array}$ & $\begin{array}{l}\text { conv. } \\
\text { pitfall }\end{array}$ & $\begin{array}{l}\text { pitfall } \\
+ \text { roof }\end{array}$ & $\begin{array}{c}\text { funnel } \\
\text { pitfall }\end{array}$ & $\begin{array}{c}\text { funnel pitfall } \\
+ \text { roof }\end{array}$ \\
\hline Amphibians & 1 & 1 & 1 & 0 & 8 & 3 & 0 & 0 \\
\hline Reptiles & 1 & 2 & 0 & 0 & 0 & 0 & 0 & 0 \\
\hline S. mammals & 2 & 2 & 0 & 0 & 12 & 11 & 1 & 0 \\
\hline
\end{tabular}

Table S5. Estimated residual variances and variances of the random intercept. S - small $(<10 \mathrm{~mm})$, $\mathrm{L}$ - large (>10 mm), F1 - non-flying, F2 - flying possible, F3 - flying, $\mathrm{H}$ - habitat, $\sigma^{\wedge}$ - residual variance, $d^{\wedge}$ - variance of the random intercept.

\begin{tabular}{|c|c|c|c|c|c|c|c|}
\hline \multicolumn{4}{|c|}{ Carabids } & \multicolumn{4}{|c|}{ Spiders } \\
\hline & & Habitat & H/Site & & & Habitat & H/Site \\
\hline & $\sigma^{\wedge}$ & $d^{\wedge}$ & $d^{n}$ & & $\sigma^{\wedge}$ & $d^{n}$ & $d^{\wedge}$ \\
\hline $\mathrm{N}$ & 2.227 & 0.782 & 0.464 & $\mathrm{~N}$ & 2.168 & 0.184 & 0.165 \\
\hline S-F1 & 1.635 & 0.758 & 0.666 & Large N & 1.016 & 0.286 & 0.302 \\
\hline S-F2 & 1.298 & $<0.001$ & 0.771 & Small N & 2.120 & 0.229 & 0.174 \\
\hline S-F3 & 1.276 & 0.832 & 0.652 & Ground N & 2.171 & 0.223 & 0.171 \\
\hline L-F1 & 1.605 & 0.439 & 0.711 & Vegetation $\mathrm{N}$ & 1.071 & 0.109 & 0.290 \\
\hline L-F2 & 1.468 & 1.452 & 0.393 & & & & \\
\hline L-F3 & 1.529 & 1.413 & 0.745 & & & & \\
\hline
\end{tabular}

